\title{
Global Imaginings: Imagining the Teacher
}

Sue Thomas

Griffith University

Maxine Cooper

Ballarat University

\begin{abstract}
The article examines the effects of globalisation on teacher education students. The authors analyse some of the responses of a group of international teacher education students to such issues as their perceptions of globalisation, cultural diversity and cultural understandings of teachers' professional identities.
\end{abstract}

Keywords: cultural diversity, globlisation, cultural identities, international students, teachers identities

\section{Introduction}

Our current times are characterised by the processes of globalisation, which feature, among other elements, the movements of peoples on a global scale not previously experienced. Such global movements have resulted in increasingly diverse cultures and in the global imaginings of diverse cultural identities. Diversity, both in cultures and in identities, is a feature of all institutions in a globalised society, including education. In Australia, the global movements of people have meant increasingly diverse student populations in classrooms and in teacher education. Further, teacher education students from diverse cultural backgrounds construct, or imagine, particular professional identities of teacher and of teaching and learning. These imaginings shape both their expectations and their experiences of pre-service teacher education programs.

This article explores these ideas further as it examines the thoughts of one group of international teacher education students on their cultural understandings of teachers' professional identities and on teaching and learning. First, it discusses globalisation, which is 
understood as a complex process with social, political, economic and cultural dimensions. The article notes the need to analyse these processes of globalisation. Of particular interest are the processes of cultural globalisation that result in the imagining of diverse cultural identities. Next, the article discusses the impact of cultural globalisation on teacher education, applying the ideas discussed in the previous section to the notion of teacher professional identity. Finally, the article outlines the findings of an initial study that questions teacher education students' imaginings of diverse teacher professional identities through a pre-service teacher education program. The article argues that further research in this area will help us to understand the way teacher education programs can work to meet the cultural and educational needs of teachers as they meet the challenges for education in a globalised world in the 21 st century.

\section{Globalisation, Global Movements and Diverse Cultural Identities}

Globalisation is understood to be the 'accelerated international flows of goods, capital, labour, services, and information that have occurred in response to improved transport, the seemingly limitless revolution in communications technologies, and the deregulatory policies adopted in many countries during the past two decades' (Green, 1999: 57). Globalisation is, therefore, both complex and multiple (Marginson, 1999). It is not a unitary 'reality' (Gough, 1999). Nor is it an homogeneous (Dale, 1999), or a convergent and unifying, phenomenon (McCarthy \& Dimitriades, 2000). Rather, globalisation is about linkages and interconnections between states and world systems (Marginson, 1999). Such systems have a life of their own that is distinct from national and local life. At the same time, these world systems tend to determine the local and national.

Further, globalisation has social, political, economic and cultural dimensions [emphasis added] (Appadurai, 1996; Rizvi, 2000; Smelser, 2003). For example, the current phase of globalisation is characterised by increasing cultural flows between nations, which in turn, lead to the reconfiguration of cultural identities (Rizvi, 2000). Therefore, the complexities of globalisation cannot be explained in economic terms alone. Rather an understanding of globalisation requires an approach that looks at the changing social, political and cultural landscapes (Rizvi, 2000). We need to go beyond definitions, to examine what globalisation does and how it does it in particular social and cultural contexts (Gough, 1999). This article is concerned with cosidering the impact of the processes of cultural globalisation on teacher education. 
Cultural globalisation is 'typified by a set of practices that are transcultural, emerging out of rapid flows of cultures across national boundaries, not only through global media and information technologies but also through the movement of people' (Rizvi, 2000: 208). As Marginson (1999) notes, the global movement of people is easier now than at any other time. New global cultural flows arising from such migrations shape new constructions of local identity and community (Singh, 2004). Further, the increasing global movement of ideas, images and people works together with the increasing dominance of media and communication technologies to result in a greater pluralism of languages, dialects and cultures of practice. That is, migration and media provides resources for experiments for self-making and enables a broader range of subjectivities to form (Marginson, 1999). In addition, new media and communication technologies enable migrants to 'manage their own diasporic identities while resisting full assimilation into the new nation' (Marginson, 1999: 22). The notion of culturally homogeneous nations is difficult to sustain and there is less likelihood of coherent cultural group identities. As Popkewitz (2000) notes, the social, collective idea of a nation is being challenged by cultural struggles over subjectivities.

There is a tension between the fragmentation resulting from the rise of these diverse, locally oriented identities and the cultural homogeneity that is also a product of globalisation (Burbules \& Torres, 2000). That is, cultural heterogeneity and cultural homogeneity appear simultaneously in dialectical, 'glocal' tension. Globalisation, therefore, leads to a dialect of identities, to both the strengthening of local identities and to the production of new identities (Hall, 1992). Thus, the global movements of people raises complex issues of identity and authenticity, and these issues of identity are inextricably linked to the dialectical tensions between the local and the global, tensions that are a characteristic feature of cultural globalisation.

\section{Imagining the Teacher}

As features of cultural globalisation, identities, therefore, are understood to be dynamic, emergent forms of collective action that are constituted in a system of social relations and representations, and shaped through cultural struggles that require the reciprocal recognition of others (Popkewitz, 2000; Rizvi, 2000). Further, Hall (1992), discussing the notion of national identity, notes that identity is formed and transformed in its relation to systems of representation. That is, people are not only citizens of a nation, but participate in the idea of the nation as it is represented through cultural meanings. In a globalised world, the media and migration are potent sources for these ideas. That is, media and immigration offer new resources for the con- 
struction of imagined selves and imagined worlds.

As Appadurai (1996) argues, the new media and technological change have led to imagination becoming a collective social fact. Imagination is the basis of the plurality of imagined worlds as ordinary people deploy their imaginations in the practice of their everyday lives. Imagination in its collective forms, creates a 'community of sentiment', a group that begins to imagine and feel things together. That is, the new media and migration impel the work of the imagination, transforming everyday subjectivities, and creating diasporic public spaces in which group identities are constituted by differences among others (Appadurai, 1996). These diverse identities are constructed discursively and materially (Hall, 1992; McCarthy \& Dimitriades, 2000). Thus, the imagination works to construct diverse, hybrid identities through struggles over difference. Such struggles are evident in the educational reforms currently impacting on teaching and teacher education (Popkewitz, 2000).

Education is a significant site for the struggles of cultural globalisation. Indeed, Marginson (1999), describes education as a primary medium of globalisation, which has the potential to affect educational institutions, policies, and programs. For example, the global transmission of policies and practices increasingly ignores national and cultural boundaries resulting in policy convergence (Green, 1999), where policy discourses and objectives in various countries become increasingly similar over time. Educational policy discourses work not only to define educational practices but also to construct particular teacher identities (Thomas, 2004). Similarly, electronic media construct particular teacher identities, identities that cross national boundaries (Gale \& Densmore, 2001; Giroux, 1997; Weber \& Mitchell, 1995).

Gee (2001) sees identity as referring to the way actors are recognised as a certain kind of person in a particular social context. Following from this, teachers' professional identity may be understood to refer to how teachers are recognised as a teacher in a given context by others. However, professional identity refers also to the way teachers perceive themselves as a group (Beijaard, Maijer, \& Verloop, 2004; Chouliaraki $\&$ Fairclough, 1999). That is, as noted earlier, people are not only members of a particular group, they participate in the idea of that group. Thus, teachers' professional identities are collective or organisational identities imagined by teachers as institutional agents. That is, teachers are not only teachers, but participate in the idea of teacher. They imagine the teacher. How the teacher is imagined, and how these imaginings influence teachers' understandings of teaching and learning is an area that needs to be explored further. Such explorations will make 
a significant contribution to the study of teacher professional identity, an emerging area in educational research that needs further work (Beijaard et al., 2004).

\section{Researching Diverse Teacher Professional Identities}

A fruitful area for further research into teacher professional identities is to investigate how teacher education students from culturally diverse backgrounds imagine the teacher in a teacher education context. The following section outlines findings from one such study, which is concerned with the construction of teachers' professional identities as distinct from national/ethnic identities. This initial research examines how global movements impact on teacher education programs. In particular, it explores how the diverse cultural experiences of teacher education students contribute to the construction of teachers' professional identities; to the interrelationships between teacher identities and understandings of teaching and learning; and, hence, to teachers' ability to teach in complex settings with diverse students taking account of local and global concerns. A crucial focus of this study is what these issues mean for teacher educators.

The research questions that guide this study are:

What is the impact of globalisation on teacher professional identities?

How do teacher education students from diverse cultural backgrounds identify as a teacher?

What was their understandings of effective teaching and learning practices?

What are their cultural understandings about teachers, teaching and learning prior to beginning the teacher education program?

In what ways do these cultural understandings change throughout the program?

The initial investigations for the small pilot study took the form of an electronic survey of students completing a Master of Teaching program, a postgraduate pre-service program for overseas students in an Australian University. The majority of students in the program were from Canada, and all the respondents to the survey were Canadian. Students were asked to comment on their understandings of what it means to be a teacher; the extent to which these understandings had been affected by their experiences in Australia; the differences between their undergraduate teaching and learning experiences from their Australian experiences; how these experiences had affected their understandings of effective teaching and learning; and perceived cultural differences between Australia and the country in which they completed their first degree. While the number of respondents to the 
survey was small, their responses indicated areas for further research into imagining the teacher.

Students' responses revealed that they were beginning to imagine themselves as 'teacher' rather than 'student' as they outlined how they imagined the teacher. Teachers were perceived as being highly trained professionals who can shape the future and, who have the capacity to teach children how to interact with other people in the world. As one student responded:

I believe that the point in being a teacher is to be able to mould the future and make it a better place by teaching the children not only how to live their own lives but how to interact in the world with other people. Teaching is not what everyone thinks. It is a demanding job but in the end you know your work is well worth the effort when you see the smiles on the little faces of those whom you have had an impact on. Being a teacher takes a strong person, someone with personal qualities such as empathy, sympathy, friendship, humour etc and someone who is highly trained in the areas they are about to teach.

As well as shaping the future and working with children to interact in the world, personal qualities such as strength, empathy and humour, were deemed important.

Other qualities emphasised were passion, empathy, dedication and resourcefulness, qualities that enabled them to respond to a diverse classroom population. For example, one student noted:

I believe a teacher must dedicate themselves to reach out to each student in the class and apply a range of activities that will accommodate the struggling student as well as the thriving student. This requires a great deal of resourcefulness on the part of the teacher, as well as the ability to be flexible and make changes when something needs to be assessed. I acknowledge how difficult it is to be a teacher, to follow each child, and how there is only so much one-on-one a teacher can provide with a class of 25 or more.

Both of these students indicated they realised the demands, difficulties and need for dedication in the daily work of teachers but could also see the rewards of feeling you were making a difference to the lives of students and to contributing to making the world a 'better place'. These students imagined the teacher as being socially just and equitable and meeting the diverse needs of both the 'struggling' and the 'thriving' student. Their imaginings may be influenced by a global vision of a more equitable and socially just world

In addition, students stressed the importance of their professional practice experiences, which they referred to as the practicum, or sim- 
ply "prac". In particular, students drew on these experiences when responding to questions about their understandings of 'teacher'.

My prac experiences showed me just how much work goes into being a teacher. Much more time and effort than realized.

My understanding of teaching was that it was a profession that stayed at work and did not enter our personal lives, being here made me realize this was not true.

These responses indicated that students have begun to really appreciate that teaching is hard work and requires effort and a professional approach. The students are beginning to appreciate that teaching is a difficult challenge, but worth the effort. There appears to be a sense of the students' imaginings of the teacher as having an effect on their own constructions of practice and their own ways of behaving and acting as a teacher in their daily life of the school.

Another significant feature in students' responses to this question was the use of metaphors to describe teachers' work. Students used a variety of metaphors, including that of an education coach and referee and of swimming.

I thought (coming from an academic school in what I think was a more academic government setting) teachers would be more authoritative. I have learned that a teacher is more of an education coach and referee. Most of my time is spent on behaviour management. The students I have seen are not academic. Teachers are basically coaches who lack the authority to enforce their decisions.

In business it is sink or swim. In teaching it is our job as an educator to make sure everyone swims.

The idea of the teachers as coach, making sure that everyone swims in the experience of learning, has elements of the idea of teacher as facilitator encouraging and assisting all students equitably. This reinforces the idea discussed previously of the teacher as a person able to assist the 'stuggling' student to achieve his/her full potential. These metaphors have been drawn from many sources, including the student's discipline area, as indicated by the reference to business. Interestingly, the metaphors used do not appear to be culturally specific. They point instead to the global understandings of the teacher. Their use in this small sample indicates that an analysis of metaphors for "teacher" could be a fruitful area of further investigation.

Also worthy of further investigation were the responses of some of 
these students to questions of differences in understandings of teaching and learning. Of particular significance were responses concerning academic challenge. Some students indicated that their undergraduate study was more academically challenging. However, their responses did not contain enough detail to explain why they believed this to be the case. This was a direct consequence of the methodological tool employed, that is, an electronic survey. However, some indication can be gained by the emphasis on lectures in the undergraduate program. One student attempted to explain the difference in learning experiences in terms of her theoretical understandings of effective teaching and learning.

They were entirely different. Uni is all about lectures where as the Master of Teaching degree focussed on group work assessment tasks and workshops to equip us for the future of teaching concerning staff interaction. Also the strong focus on inquiry based learning redirects effective teaching and learning to the students.

The perceived differences in teaching and learning experiences may be influenced by the students' previous area of study, e.g. Biotechnology; by gender, the question of academic challenge was raised most frequently by male students; or by cultural differences. One student, for example, recognised that cultural differences impacts on understandings of teacher.

Obviously learning to teach in another country, culture and education system has made me more aware of diversity in the classroom and the things that affect a teacher professionally.

Clearly the academic level of study is at a post graduate level but the students are enrolled in a pre-service program, in terms of their experience and qualifications as a teacher. Until the students have begun to practice the art of teaching; to conceptualise and theorise their teaching practices; and to 'practice their practices'; the development of understanding teaching and learning will be an ongoing challenge. Once again, more investigation is needed to ascertain if understandings of 'academic challenge' are culturally specific, and if so, how these understandings impact on students' experiences in our teacher education programs.

\section{Conclusion: Teachers in the Twenty-first Century}

In conclusion, this article discussed the impact of cultural globalisation on teacher education programs, particularly in terms of the increasing diversity of teacher education student populations. It raised questions about how such a diverse teacher education student body imagined teachers, and how these imaginings impacted on the 
construction of their professional identity as teachers and on understandings of teaching and learning.

The article reported on initial findings from a pilot study that indicated that teacher education students from diverse cultural backgrounds share a global imagining of the teacher. They perceived teachers as being, and recognised themselves as becoming, dedicated, highly trained professionals, reflecting an idealistic commitment to working for equity and diversity. These initial findings point to the need for further research on how teacher education students imagine the teacher, and on how they construct a professional identity through their pre-service teacher education programs.

Further research exploring these issues of teacher identity, teacher education, globalisation, cultural differences, social inclusion and exclusion at a local, national and international level is continuing. It is based on an understanding of teaching as cosmopolitan work that is in critical and contingent relation to the flows, contexts and consequences of cultural and economic globalisation (Luke, 2004). Such research is significant in that it will give insights into the development of local and global 'communities of practice' through networks and 'productive pedagogies'. It will give also insights into how teachers, schools and teacher education programs can work in partnership to produce quality teachers for the 21st century. By furthering our understandings of how the flows of cultural globalisation impact on teachers' professional identities, this research will contribute to a powerful, new strategic vision of teachers and teaching for a new era.

\section{References}

Appadurai, A. (1996). Modernity at Large Cultural Dimensions of Globalisation. Minneapolis: University of Minnesota Press.

Beijaard, D., Maijer, P. C., \& Verloop, N. (2004). Recondisering research on teachers' professional identity. Teaching and Teacher Education, 20, 107-128.

Burbules, N. C., \& Torres, C. A. (2000). Globalization and education: An introduction. In N. C. Burbules \& C. A. Torres (eds.), Education And Globalization Critical Perspectives (pp. 1-25). New York: Routledge.

Chouliaraki, L., \& Fairclough, N. (1999). Discourse in Late Modernity Rethinking Critical Discourse Analysis. Edinburgh: Edinburgh University Press.

Dale, R. (1999). Specifying globalization effects on national policy: A focus on the mechanisms. Journal of Education Policy, 14, 1: 1-17.

Gale, T., \& Densmore, K. (2001). Questions of (re)production and legitimation: A second screening of three films on teacher-student relations. Journal of Curriculum Studies, 33, 5: 601-619.

Gee, J. P. (2001). Identity as an analytic lens for research in education. In W. G. Secada (ed.), Review of Research in Education (Vol. 25, pp. 99-125). 
Washington, DC: American Educational Research Association.

Giroux, H. A. (1997). Race, pedagogy, and whiteness in dangerous minds. Cineaste, 22, 4: 46-49.

Gough, N. (1999). Globalization and school curriculum change: Locating a transnational imaginary. Journal of Education Policy, 14, 1: 73-84.

Green, A. (1999). Education and globalization in Europe and East Asia: Convergent and divergent trends. Journal of Education Policv, 14, 1: 55-71.

Hall, S. (1992). The question of cultural identity. In S. Hall, D. Held \& T. McGrew (eds.), Modernity and Its Futures (pp. 274-316). Cambridge: Polity Press in association with the Open University.

Luke, A. (2004). Teaching after the market: From commodity to cosmopolitan. Teachers College Record, 106, 7: 1422-1443.

Marginson, S. (1999). After globalization: Emerging politics of education. Journal of Education Policy, 14, 1: 19-31.

McCarthy, C., \& Dimitriades, G. (2000). Globalizing pedagogies: Power, resentment, and the re-narration of difference. In N. C. Burbules \& C. A. Torres (eds.), Education and Globalization Critical Perspectives (pp. 187-204). New York: Routledge.

Popkewitz, T. S. (2000). Reform as the social administration of the child: Globalization of knowledge and power. In N. C. Burbules \& C. A. Torres (eds.), Education and Globalization Critical Perspectives (pp. 157-186). New York: Routledge.

Rizvi, F. (2000). International education and the production of global imagination. In N. C. Burbules \& C. A. Torres (eds.), Education and Globalization Critical Perspectives (pp. 205-225). New York: Routledge.

Singh, P. (2004). Globlization and education. Educational Theory, 54, 1: 103-115.

Smelser, N. J. (2003). Pressures for continuity in the context of globalization. Current Sociology, 51, 2: 101-112.

Thomas, S. (2004). Reconfiguring the public sphere: implications for analyses of educational policy. British Journal of Educational Studies, 52, 3: 228-248.

Weber, S., \& Mitchell, C. (1995). 'That's Funny, You Don't Look Like a Teacher'. Interrogating Images and Identity in Popular Culture. London: The Falmer Press. 